J. Clin. Chem. Clin. Biochem.

Vol. 27, 1989, pp. 19-25

(C) 1989 Walter de Gruyter \& Co.

Berlin - New York

\title{
Radioimmunoassay of Human Pepsinogen A and Pepsinogen $\mathrm{C}^{1}$ )
}

\author{
By I. Biemond, J. B. M. J. Jansen, L. F. S. J. Crobach, Johanna Kreuning and C. B. H. W. Lamers \\ Afdeling Maag-, Darm- en Leverziekten, Academisch Ziekenhuis, Leiden, The Netherlands
}

(Received June 29/October 21, 1988)

Summary: We describe the development of radioimmunoassays to measure both human pepsinogen $\mathrm{A}$ and pepsinogen $\mathrm{C}$ concentrations in serum. The antibodies were raised in goats by immunization with purified pepsinogen $A$ or $C$. The affinity constants of the respective antibodies were $20 \cdot 10^{10} \mathrm{l} / \mathrm{mol}$ and $7 \cdot 10^{10} \mathrm{l} / \mathrm{mol}$.

Pepsinogens $\mathrm{A}$ and $\mathrm{C}$ were labeled with $\mathrm{Na}{ }^{125} \mathrm{I}$ by the chloramine $\mathrm{T}$ method. The binding between labels and antibodies was inhibited by 0.50 at $0.82 \mathrm{ng}$ pepsinogen $\mathrm{A}$ per tube and $2.1 \mathrm{ng}$ pepsinogen $\mathrm{C}$ per tube. The detection limits of the assay of pepsinogen $A$ and $C$ were $0.12 \mu \mathrm{g} / 1$ and $1.8 \mu \mathrm{g} / \mathrm{l}$, respectively.

Pepsinogen $\mathrm{A}$ and $\mathrm{C}$ were purified and added to a patient serum, showing a good recovery in the radioimmunoassays. Serial dilution of another patient serum, which contained a high concentration of both antigens, showed curves parallel to the standard curves. The intra- and interassay variations of these radioimmunoassays were evaluated. The intra-assay coefficients of variation for pepsinogen A were found to vary from 0.03 to 0.102 at concentrations in serum in the normal range, while the inter-assay coefficient of variation ranged from 0.118 to 0.194 at the same concentrations in serum. For the pepsinogen $C$ radioimmunoassay we found intra-assay coefficients of variation between 0.126 and 0.147 at concentrations in serum in the normal range, while the inter-assay coefficient of variation ranged from 0.174 to 0.325 for the same sera.

In 201 blood donors we found a mean serum concentration of pepsinogen $A$ of $59 \mu \mathrm{g} / 1$ and a mean serum concentration of pepsinogen $\mathrm{C}$ of $15 \mu \mathrm{g} / \mathrm{l}$. There was a significant relationship between these values $(\mathrm{r}=0.779$, $\mathrm{p}<0.001)$.

The concentrations of both pepsinogens were increased in 10 patients with duodenal ulcer (132 and $67 \mu \mathrm{g} / \mathrm{l}$, respectively). Serum pepsinogen A was decreased in 14 patients with partial gastrectomy $(34 \mu \mathrm{g} / \mathrm{l})$ and in 6 with achlorhydria $(9 \mu \mathrm{g} / \mathrm{l})$, accompanied by raised $(34 \mu \mathrm{g} / \mathrm{l})$ and normal $(20 \mu \mathrm{g} / \mathrm{l})$ mean pepsinogen $\mathrm{C}$ concentrations in the respective groups. In 4 patients with a total gastrectomy the mean serum concentration of both pepsinogen $A$ and $C$ reached the zero level ( 5 and $4 \mu \mathrm{g} / \mathrm{l}$, respectively). These results not only underline the accuracy of the measurements but also point to their clinical relevance.

\section{Introduction}

Pepsinogen $\mathrm{A}$ and $\mathrm{C}$ are the proenzymes of pepsin $\mathrm{A}$ and pepsin $C$, respectively, which belong to the group of gastric acid aspartic endoproteinases. Pepsinogen $A$ is secreted by fundic mucosa, while pepsinogen $C$

\footnotetext{
') Enzymes:

Pepsin A; EC 3.4.23.1

Pepsin C; gastricsin; EC 3.4.23.3
}

is secreted by fundic, pyloric and proximal duodenal mucosa (1). Exocrine-secreted pepsinogens function as zymogens for the main proteolytic activity of gastric juice. There is also a small endocrine excretion of pepsinogens without a known function, but by exploiting this phenomenon, we can gain information on the condition of the gastric mucosa by measurement of the serum concentration of pepsinogen $A$ and pepsinogen $C(2,3)$. 
As the concentration of both zymogens in serum is low, we developed a radioimmunoassay to measure pepsinogen $A$ and $C$ in serum. This report describes a protocol for the isolation of pepsinogen $\mathrm{A}$ and $\mathrm{C}$ from gastric mucosa, the production of antibodies against these antigens in goats, the conditions of the radioimmunoassay, and the distribution of serum pepsinogen $A$ and $C$ in blood transfusion donors and in patients with duodenal ulcer, atrophic gastritis, and partial or total gastrectomy.

\section{Materials and Methods}

\section{Reagents}

$\mathrm{Na}{ }^{125} \mathrm{I}$ was purchased from New England Nuclear, Boston, MA, USA; diethylaminoethyl(DEAE)-Cellulose DE-52 from Whatman. Maidstone, England, UK; Sephadex ${ }^{\star 1}$ G 100, PD$10^{\oplus}$ columns, Mono ${ }^{\oplus}$ (high pressure resistant monodisperse anion exchanger), and decanting suspension 2 (Micro-Sepharose $^{\text {Dod }}$ beads coupled with horse anti-sheep/goat immunoglobulin antibodies) from Pharmacia, Uppsala, Sweden; cellulose dialysis membrane, disodium ethylene-diaminetetraacetic acid (EDTA), bis[2-hydroxyethyl]imino-tris-[hydroxymethyl]-methane(BIS-TRIS), and bovine haemoglobin from Sigma, St. Louis, MO, USA; all other reagents from E. Merck, Darmstadt, F. R. G. Nonimmune horse serum was oblained from a local abattoir.

\section{Equipment}

Radioactivity was measured by an automatic gamma-scintillation counter, the Clinigamma 1272, with four 1.5 inch $\mathrm{NaI}$ crystals from Wallac Oy, Turku, Finland. High pressure anion exchange chromatography was performed with the FPLC system from Pharmacia, Uppsala, Sweden.

\section{Gastric mucosa}

The stomach of a patient with a Zollinger-Ellison syndrome was cut open along the minor curvature. The mucosa from the corpus was stripped off the muscle layer, divided in parts and frozen.

\section{Isolation of pepsinogen $\mathrm{A}$ and pepsinogen $\mathrm{C}$}

After thawing, the mucosa was homogenized in $0.02 \mathrm{~mol} / 1$ phosphate buffer, pH 7.5 (3 ml/g of tissue) with a Sorvall ${ }^{\oplus}$ Omnimixer at maximum speed for 3 minutes on ice. The homogenate was centrifuged at $36500 \mathrm{~g}$ at $4{ }^{\circ} \mathrm{C}$ for 15 minutes. The supernatant was decanted and once more centrifuged at $100000 \mathrm{~g}$ at $4^{\circ} \mathrm{C}$ for 60 minutes. After decanting, the supernatant was dialysed overnight against the same buffer.

The retentate was applied to the top of a column $(2.6 \times 40$ $\mathrm{cm}$ ) packed with DEAE-Cellulose to a bed height of $17 \mathrm{~cm}$ and equilibrated with the above described phosphate buffer. The column was washed with $125 \mathrm{ml} 0.1 \mathrm{~mol} / 1 \mathrm{NaCl}$ in the equilibration buffer. The pepsinogens were eluted in a single peak by a linear gradient of $200 \mathrm{ml}$ ranging from $0.10 \mathrm{~mol} / \mathrm{l}$ to 0.48 $\mathrm{mol} / 1 \mathrm{NaCl}$ in the equilibration buffer. The eluate fractions containing most proteolytic activity were pooled and dialysed against phosphate buffer.

The pooled pepsinogens were further purified by gel permeation chromatography on a $2.6 \times 100 \mathrm{~cm}$ column with a flow adaptor packed with Sephadex ${ }^{\boxplus} \mathrm{G} 100$ to a bed height of $93 \mathrm{~cm}$ in phosphate buffer at $4^{\circ} \mathrm{C}$.
All material from the Sephadex G100 absorbing at $280 \mathrm{~nm}$, was adsorbed to Mono $Q^{\star}$ anion exchanger, then separated into pepsinogen $C$ and pepsinogen A by FPLC (fig. 1). The peaks of pepsinogen $A$ were pooled and apart from the pepsinogen $C$ peak thoroughly dialysed against distilled water and lyophilized.

\section{Analytical methods}

Proteolytic activity was monitored in colúmn eluate fractions by incubating $0.1 \mathrm{ml}$ of an appropriate dilution of sample with $2.5 \mathrm{ml}$ bovine haemoglobin solution $(2.5 \mathrm{~g} / \mathrm{l}$ bovine haemoglobin in $0.06 \mathrm{~mol} / 1 \mathrm{HCl}$ ) at $37^{\circ} \mathrm{C}$ for $10 \mathrm{~min}$. The reaction was stopped with $5.0 \mathrm{ml}$ of $0.31 \mathrm{~mol} / \mathrm{l}$ trichloroacetic acid. The digest was filtered, and the absorbance of the filtrate was determined at $280 \mathrm{~nm}$.

FPLC ${ }^{\oplus a s}$ performed according to Défize et al: (4). Pepsinogens in phosphate buffer were applied to a $0.5 \times 5 \mathrm{~cm}$ column, packed with Mono $\mathrm{Q}^{\oplus}$, and equilibrated in $0.025 \mathrm{~mol} / \mathrm{l} \mathrm{BIS}$ TRIS/hydrochloric acid, $\mathrm{pH}$ 6.0. The column was washed with $4 \mathrm{ml} 0.12 \mathrm{~mol} / 1 \mathrm{NaCl}$ in equilibration buffer, and the pepsinogens were eluted with $21 \mathrm{ml}$ of a linear gradient of $\mathrm{NaCl}$ in equilibration buffer, ranging from 0.12 to $0.4 \mathrm{~mol} / 1$. Fractions of $0.5 \mathrm{ml}$ were collected. Absorbance at $280 \mathrm{~nm}$ was continuously measured in the eluate.

\section{Antibody production}

Antibodies to pepsinogen $\mathrm{A}$ and pepsinogen $\mathrm{C}$ were raised in two different goats. Primary immunization was done by subcutaneous injection of an emulsion of $1 \mathrm{ml}$ Freund's complete adjuvant and $1 \mathrm{ml}$ solution of antigen in saline $(1 \mathrm{~g} / \mathrm{l})$. The animals were boosted by monthly injections of an emulsion of $1 \mathrm{ml}$ Freund's incomplete adjuvant and $1 \mathrm{ml}$ solution of antigen in saline $(0.5 \mathrm{~g} / \mathrm{l})$, and bled at two week intervals. The injection scheme was continued for more than two years.

Dilution curves of goat anti-pepsinogen A for 4 different bleeding times were compared and the best selected. A goat antipepsinogen $C$ antiserum, taken at a randomly chosen bleeding time, showed an appropriate dilution curve.

\section{Radioiodination}

Pepsinogens $\mathrm{A}$ and $\mathrm{C}$ were labeled with $\mathrm{Na}{ }^{125} \mathrm{I}$ by the chloramine $T$ method (5). The incubation mixture contained $5 \mu \mathrm{g}$ pepsinogen $A$ or pepsinogen $C$ in $5 \mu \mathrm{l} 0.05 \mathrm{~mol} / \mathrm{l}$ phosphate buffer, $\mathrm{pH} 7.5,20 \mu \mathrm{l} 0.5 \mathrm{~mol} / 1$ phosphate buffer, $\mathrm{pH} 7.5,5 \mu \mathrm{l}$ $\mathrm{Na}{ }^{125} \mathrm{I}$ solution $(3700 \mathrm{GBq} / \mathrm{l})$ and $10 \mu \mathrm{g}(10 \mu \mathrm{l})$ chloramine $\mathrm{T}$. The mixture was incubated for $30 \mathrm{~s}$ at $0^{\circ} \mathrm{C}$. The reaction was stopped by addition of $20 \mu \mathrm{g}(10 \mu \mathrm{l})$ sodium metabisulphite and diluted with $1.0 \mathrm{ml} 0.05 \mathrm{~mol} / 1$ phosphate buffer, $\mathrm{pH} 7.5$.

Labeled pepsinogens and inorganic ${ }^{125} \mathrm{I}$ were separated on a PD-10 eluted with $0.05 \mathrm{~mol} / \mathrm{l}$ phosphate buffer, $\mathrm{pH} 7.5$. Eluate fractions of $1.0 \mathrm{ml}$ were collected into tubes containing $10 \mu \mathrm{l}$ horse serum. The fraction next to the void volume fraction was used and diluted in $0.01 \mathrm{~mol} / \mathrm{l}$ phosphate-buffered saline containing $10 \mathrm{ml} / \mathrm{l}$ horse serum.

\section{Radioimmunoassays}

Pepsinogen $\mathrm{A}$ and pepsinogen $\mathrm{C}$ were both measured by a competitive binding assay in which bound and free antigen were separated by Micro-Sepharose beads coupled to horse anti sheep/goat immunoglobulin antibodies. The diluent buffer was a mixture of 6 volumes $0.01 \mathrm{~mol} / 1$ phosphate buffered saline, $\mathrm{pH} 7.5$, and one volume $0.1 \mathrm{~mol} / \mathrm{l} \mathrm{EDTA}$ in water, 
supplemented with $10 \mathrm{ml} / 1$ nonimmune horse serum. Diluent buffer, antiserum dilution, standards or test sera were added to $11.5 \times 55 \mathrm{~mm}$ disposable polystyrene tubes to a final volume of $1 \mathrm{ml}$.

For the radioimmunoassay of pepsinogen $A$ the incubation mixture contained $400 \mu$ l diluent buffer, $200 \mu$ l pepsinogen $A$ standard or 10-fold diluted test serum, $200 \mu \mathrm{l}$ goat anti-pepsinogen $A$ in a final dilution of $1: 300000$, and $200 \mu \mathrm{l}^{125} \mathrm{I}$-labelled pepsinogen $A$ in diluent buffer to provide about 4000 counts/ $\min (120 \mathrm{~Bq}$ per tube).

For the radioimmunoassay of pepsinogen $\mathrm{C}$ the same scheme was applied but ${ }^{125}$ I-labelled pepsinogen $C$ was used as label, goat anti-pepsinogen $C$ was used in a final dilution of $1: 200000$, and the test sera were used in a 5-fold dilution in buffer.

After incubation for $96 \mathrm{~h}$ at $4^{\circ} \mathrm{C}, 200 \mu \mathrm{l}$ decanting suspension containing Micro-Sepharose beads coupled with horse antisheep/goat immunoglobulin antibodies was dispensed, stirred, and incubated at room temperature for 2 hours. The tubes were then centrifuged at $4500 \mathrm{~g}$ for $10 \mathrm{~min}$, the supernatant was decanted and the radioactivity of the pellet was counted for $5 \mathrm{~min}$ in a automatic gamma counter.

Standards were prepared by dissolving a weighed quantity of lyophilized pepsinogen A or C in diluent buffer. All standards and test sera were set up in duplicate. The bound radioactivity was corrected for nonspecific binding by subtracting the mean radioactivity in the nonspecific binding tubes from that in the standards and unknowns. Standard curves were calculated by linear regression of the logit transformed $B / B_{0}$ ratio with the logarithm of the standard concentration. The affinities of the antisera were calculated according to Scatchard (6).

Five control sera were used for measurement of the intra- and inter-assay variation, containing $3,27,39,81$, and $317 \mu \mathrm{g} / 1$ pepsinogen $A$ and $10,22,8,12$, and $523 \mu \mathrm{g} / \mathrm{l}$ pepsinogen $C$, respectively.

\section{Test sera}

Serum was obtained from 201 different blood transfusion donors, 130 males and 71 females, ranging in age between 18 and 64 years; from 10 patients with duodenal ulcer $(8 \delta, 2$ \%; age $21-63$ years); from 14 patients who had undergone a partial gastrectomy (12 $\%, 2$; age $27-71$ years) of which 7 had a gastroduodenostomy and the others a gastrojejunostomy; from 4 patients with a total gastrectomy ( $3 \delta, 1$ \%; age 63-84 years); and from 6 patients with achlorhydria due to atrophic gastritis ( $4 \delta, 2$ \%; age $53-78$ years).

\section{Statistical analysis}

Student's t test using a pooled or separate variance estimate, depending on the homogeneity of both variance, was applied to evaluate the significance of differences between the means of two groups. The significance of differences between the means of more than two groups was evaluated by the ratio of variances within and between groups. The level of significance was taken at 0.05 .

\section{Results}

\section{Purification and characterization}

FPLC ${ }^{\circ}$ anion exchange chromatography of the partially purified pepsinogens on Mono $\mathrm{Q}^{\oplus}$ produced 4 major peaks of absorbance at $280 \mathrm{~nm}$, all of which showed proteolytic activity (fig. 1). The ratio between

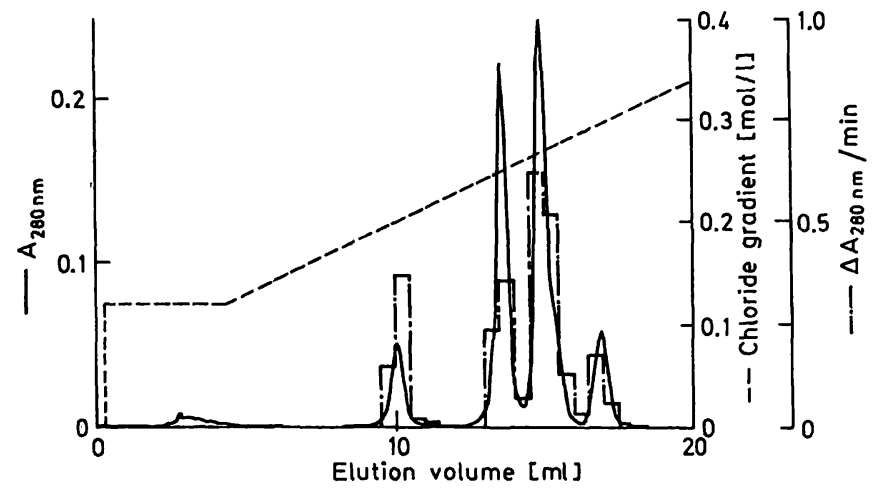

Fig. 1. FPLC ${ }^{\circ}$-gel permeation chromatography of gastric acid proteases on Mono $\mathrm{Q}^{\oplus}$ anion exchanger, using a chloride gradient. Solid line: absorbance at $280 \mathrm{~nm}$; dasheddotted line: absorbance increment at $280 \mathrm{~nm}$ per min during incubation of filtrate from bovine haemoglobin incubated with eluted fraction; dashed line: chloride gradient. The first peak eluted at $10 \mathrm{ml}$ represents pepsinogen $C$, while the following 3 peaks represent isozymogens of pepsinogen $A$.

proteolytic activities was 2.2 for the first peak and 0.8 for the 3 following peaks. The first peak, further referred to as pepsinogen $\mathrm{C}$, was immunologically distinguishable from the pooled 3 other peaks, further referred to as pepsinogen $A$; differentiation was possible with the aid of goat anti-pepsinogen $C$, which did not bind to radiolabeled pepsinogen $A$, and goat anti-pepsinogen $A$, which did not react with radioiodinated pepsinogen $C$. Furthermore, pepsinogen $C$ showed no inhibition of the binding of goat antipepsinogen $A$ and labeled pepsinogen $A$, and pepsinogen $A$ showed no inhibition of the binding between goat anti-pepsinogen $C$ and radiolabeled pepsinogen C (fig. 2).

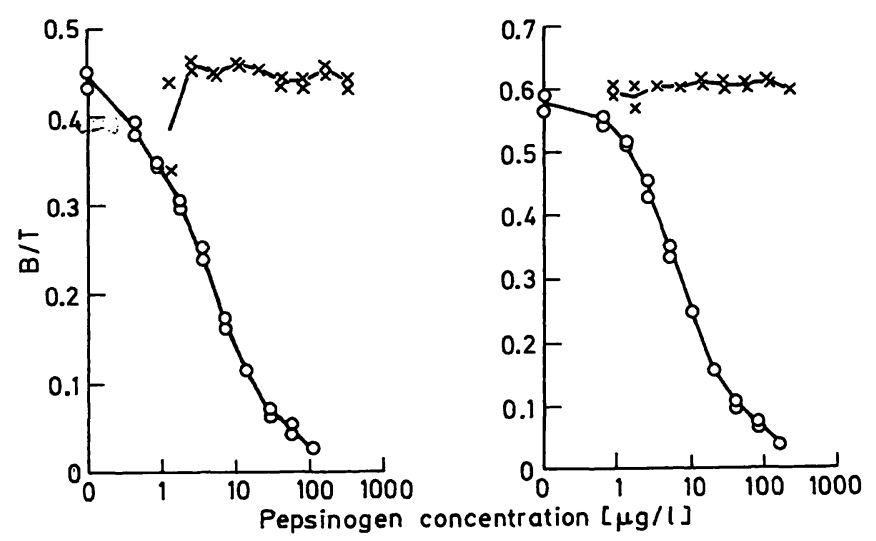

Fig. 2. Left: Ratio of bound fraction to total radioactivity versus decadic logarithm of concentration using radiolabeled pepsinogen $A$ and goat anti-pepsinogen A. Pepsinogen $A(0)$ binds to antibody, but not to pepsinogen $\mathrm{C}(\mathrm{x})$.

Right: Ratio of bound fraction to total radioactivity versus decadic logarithm of concentration using radiolabeled pepsinogen $C$ and goat anti-pepsinogen $C$. Pepsinogen $C(O)$ binds to antibody, but not to pepsinogen A (x). 


\section{Radioimmunoassay of pepsinogen $A$}

Radiolabeled pepsinogen $A$ was found to have a specific activity of $0.318 \mathrm{MBq} / \mu \mathrm{g}$. Thus each tube contained about $0.5 \mathrm{ng}$ radiolabeled pepsinogen $\mathrm{A}$. About 0.45 of radioactivity was bound by goat anti-pepsinogen $A$ serum in a final dilution of $1: 300000$. The nonspecific binding was about $0.01-0.02$. The equilibrium constant was found to be $20 \cdot 10^{10} \mathrm{l} / \mathrm{mol}$ under the conditions of the assay. The detection limit, corresponding to two standard deviations less than the mean counts bound in 5 zero standards in duplicate, was $0.12 \mu \mathrm{g} / \mathrm{l}$. The 0.50 inhibitory dose was about $0.82 \mathrm{ng} /$ tube. This high sensitivity allowed us to use the test sera in a 10 -fold dilution.

A calibration curve in which the concentration of pepsinogen A standard ranged from 0.44 to $112 \mu \mathrm{g} / \mathrm{l}$ ( 0.09 to $22.5 \mathrm{ng} /$ tube) is shown in figure 2. Pepsinogen $\mathrm{C}$ to a concentration of $340 \mu \mathrm{g} / \mathrm{l}$ did not compete in the assay (fig. 2), and goat anti-pepsinogen $C$ in a final dilution of $1: 200000$, did not bind radiolabeled pepsinogen A.

The recovery of pepsinogen A from a serum spiked with pepsinogen A standard in concentrations ranging from 0.44 to $112 \mu \mathrm{g} / \mathrm{l}$ varied between 0.813 and 1.297 with a median of 1.032 (fig. 3). A control serum containing a high concentration of pepsinogen $\mathrm{A}$ and $\mathrm{C}$ was serially 2 -fold diluted up to $1: 512$ and showed a curve parallel to the standard curve (fig. 3 ). The intra-assay coefficients of variation for pepsinogen A were found to vary from 0.030 to 0.102 at concentrations in serum in the normal range, while the interassay coefficient of variation, determined over a onemonth period, ranged from 0.118 to 0.194 at the same serum concentrations (fig. 4).
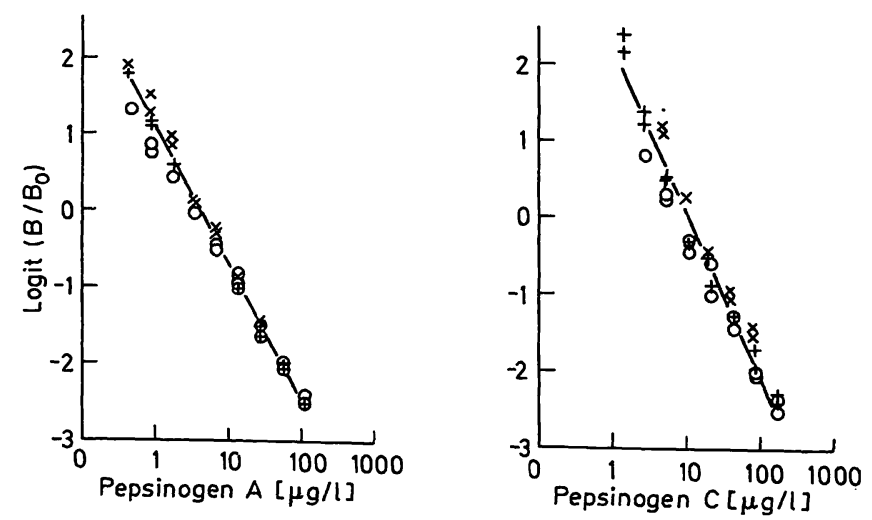

Fig. 3. Standard curve $(+)$ of logit transformed $B / B_{0}$ versus decadic logarithm of concentration using radiolabeled pepsinogen $A$ (left) or pepsinogen $C$ (right) and goat anti-pepsinogen $A$ (left) or goat anti-pepsinogen C (right).

Recovery $(0)$ of lyophilized pepsinogen A (left) or pepsinogen $C$ (right) added to a human serum.

Dilution curve $(x)$ of patient serum containing a high concentration of both pepsinogen $A$ and $C$.

\section{Radioimmunoassay of pepsinogen $C$}

Radiolabeled pepsinogen $C$ had a specific activity of $0.651 \mathrm{MBq} / \mu \mathrm{g}$. Thus each tube contained about 0.18 ng radioiodinated pepsinogen $C$. About 0.55 of radioactivity was bound by goat anti-pepsinogen $\mathrm{C}$ serum in a final dilution of $1: 200000$. The nonspecific binding was about $0.01-0.02$. The equilibrium constant was found to be $7 \cdot 10^{10} \mathrm{l} / \mathrm{mol}$ under the conditions of the assay. The detection limit, corresponding to two standard deviations less than the mean counts bound in 5 zero standards in duplicate, was $1.8 \mu \mathrm{g} / \mathrm{l}$. The 0.50 inhibitory dose was about $2.1 \mathrm{ng} /$ tube. This sensitivity allowed us to use the test sera in a 5-fold dilution.

A calibration curve in which the concentration of pepsinogen C standard ranged from 0.66 to $169 \mu \mathrm{g} / \mathrm{l}$ ( 0.13 to $34 \mathrm{ng}$ per tube) is shown in figure 2. Pepsinogen $A$ to a concentration of $225 \mu \mathrm{g} / \mathrm{l}$ did not compete in the assay (fig. 2), and goat anti-pepsinogen A in a final dilution of 1:300000 did not bind rádiolabeled pepsinogen $\mathrm{C}$.

The recovery of pepsinogen $C$ from serum spiked with pepsinogen $\mathrm{C}$ standard in concentrations ranging from 2.64 to $169 \mu \mathrm{g} / \mathrm{l}$ varied between 0.859 and 1.395 with a median of 1.159 (fig. 2). A control serum containing a high concentration of pepsinogen $\mathrm{A}$ and $\mathrm{C}$ was serially 2-fold diluted up to $1: 128$ and showed a curve parallel to the standard curve (fig. 3 ). For the pepsinogen $C$ radioimmunoassay we found an intraassay coefficient of variation between 0.126 and 0.147 at serum levels in the normal range, while the interassay coefficient of variation, determined over a onemonth period, ranged from 0.174 to 0.325 for the same sera (fig. 4).
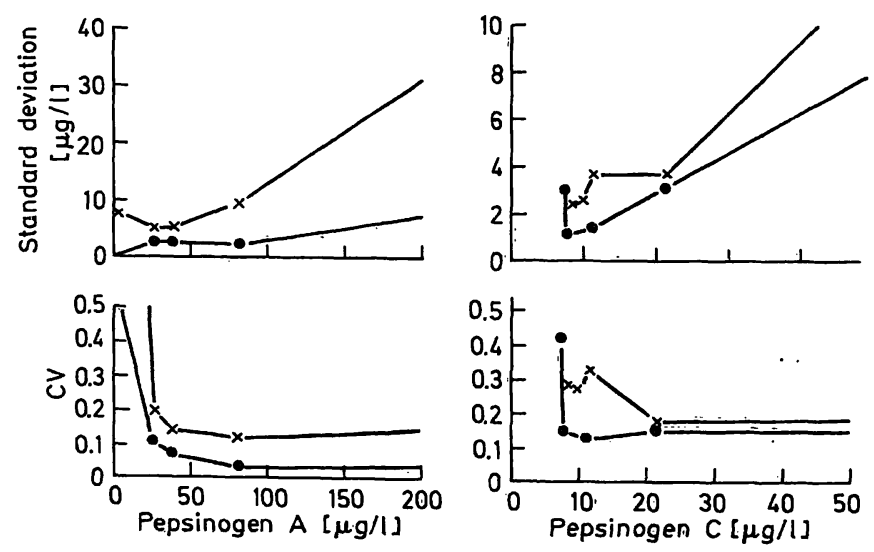

Fig. 4. Intra-assay $(0-0)$ and interassay $(x-x)$ variation expressed as standard deviation (SD) or "coefficient of variation (CV) of pepsinogen $A$ (left) and pepsinogen $C$ (right) in 6 duplicate determinations.

$\mathrm{CV}$ is given as the quotient $\mathrm{CV}=\frac{\mathrm{SD}}{\overline{\mathrm{x}}}$. 
Tab. 1. Means $(\overline{\mathbf{x}})$ and standard deviations (SD) of the concentrations of serum pepsinogens $A$ and $C(\mu \mathrm{g} / \mathrm{l})$ and the ratio of pepsinogen $A$ and pepsinogen $C$ in blood transfusion donors and different patient groups.

\begin{tabular}{|c|c|c|c|c|c|c|c|}
\hline & \multirow[t]{2}{*}{$\mathbf{n}$} & \multicolumn{2}{|c|}{ Pepsinogen A } & \multicolumn{2}{|c|}{ Pepsinogen $\mathrm{C}$} & \multicolumn{2}{|c|}{ Ratio } \\
\hline & & $\overline{\mathbf{x}}$ & SD & $\overline{\mathbf{x}}$ & $\mathrm{SD}$ & $\overline{\mathbf{x}}$ & SD \\
\hline $\begin{array}{l}\text { Blood transfusion donors } \\
- \text { males } \\
- \text { females }\end{array}$ & $\begin{array}{r}201 \\
130 \\
71\end{array}$ & $\begin{array}{l}59 \\
65^{\dagger} \\
48\end{array}$ & $\begin{array}{l}28 \\
29 \\
22\end{array}$ & $\begin{array}{l}15 \\
16 \\
13\end{array}$ & $\begin{array}{l}12 \\
12 \\
11\end{array}$ & $\begin{array}{l}5.2 \\
5.1 \\
5.4\end{array}$ & $\begin{array}{l}3.1 \\
2.4 \\
4.1\end{array}$ \\
\hline Duodenal ulcer disease & 10 & $132^{*}$ & 57 & $67^{*}$ & 25 & $2.1^{*}$ & 0.8 \\
\hline $\begin{array}{l}\text { Partial gastrectomy } \\
\text { - gastroduodenostomy } \\
\text { - gastrojejunostomy }\end{array}$ & $\begin{array}{r}14 \\
7 \\
7\end{array}$ & $\begin{array}{l}34^{*} \\
28^{*} \\
41\end{array}$ & $\begin{array}{l}29 \\
15 \\
39\end{array}$ & $\begin{array}{l}34^{*} \\
26^{*} \\
42\end{array}$ & $\begin{array}{l}31 \\
18 \\
40\end{array}$ & $\begin{array}{l}4.4 \\
4.7 \\
2.5^{*}\end{array}$ & $\begin{array}{l}7.4 \\
9.4 \\
4.2\end{array}$ \\
\hline Total gastrectomy & 4 & $5^{*}$ & 4 & $4^{*}$ & 4 & $0.5^{*}$ & 0.5 \\
\hline Atrophic gastritis & 6 & $9^{*}$ & 8 & 20 & 17 & $0.8^{*}$ & 0.7 \\
\hline
\end{tabular}

$\dagger$ significant different between males and females

* significant different from blood donors

Pepsinogen $A$ and $C$ concentrations in test sera

The mean serum concentration ( $\pm S D$ ) of pepsinogen A in blood transfusion donors was $59( \pm 28) \mu \mathrm{g} / \mathrm{l}$ (tab. 1). The serum concentration of pepsinogen $A$ showed a leptokurtic and positively skewed distribution, which could be nearly normalized by squareroot transformation. In males the mean concentration of pepsinogen $A$ in serum was $65( \pm 29) \mu \mathrm{g} / \mathrm{l}$ and in females a mean concentration of $48( \pm 22) \mu \mathrm{g} / \mathrm{l}$ was found; this difference was statistically significant (tab. 1).

Pepsinogen $C$ was found to be $15( \pm 12) \mu \mathrm{g} / \mathrm{l}$ for all blood transfusion donors (tab. 1). The serum concentration of pepsinogen $C$ showed a leptokurtic and positively skewed distribution, which could be partly normalized by square-root transformation. In contrast to pepsinogen A (tab. 1), the mean concentration in males $(16 \pm 12 \mu \mathrm{g} / \mathrm{l})$ was not statistically different from that in females $(13 \pm 11 \mu \mathrm{g} / \mathrm{l})$.

Serum pepsinogen $\mathrm{A}, \mathrm{C}$ and its ratio in relation to the age of the blood transfusion donors showed a gradual increase of both pepsinogen $\mathrm{A}$ and $\mathrm{C}$ with increasing age of the donors. The ratio tended to decrease in older people (tab. 2).

Patients with duodenal ulcer showed an increase of serum pepsinogens $\mathrm{A}$ and $\mathrm{C}$, while the ratio decreased, due to the relatively strong increase of pepsinogen $C$. Patients having undergone partial gastrectomy as well as patients with achlorhydria showed decreased levels of pepsinogen $\mathrm{A}$, but equal or even increased levels of pepsinogen $C$. The ratio also tended to decrease, and atrophic gastritis patients had an especially low ratio. Total gastrectomy caused a strong decrease in the serum concentrations of both pepsinogens and their ratio (tab. 1).

In figure 5 the pepsinogen A concentration in serum was plotted against pepsinogen $\mathrm{C}$ in both patients and blood donors. There was a highly significant overall correlation between both concentrations $(r=0.671, p<0.001)$. For blood donors and different groups of patients the correlation was found to be equally strong, except for patients with duodenal ulcer, for which the correlation coefficient was found to be much lower. The blood donors and each group of patients are characterized by their own intercept and slope of the regression line.

Tab. 2. Means and standard deviations of the concentrations of serum pepsinogens $A$ and $C(\mu \mathrm{g} / \mathrm{l})$ and the ratio of pepsinogen $A$ and pepsinogen $C$ in different age groups of blood transfusion donors.

\begin{tabular}{|c|c|c|c|c|c|c|c|}
\hline \multirow[t]{2}{*}{ Age group (a) } & \multirow[t]{2}{*}{$\mathbf{n}$} & \multicolumn{2}{|c|}{ Pepsinogen $A^{*}$} & \multicolumn{2}{|c|}{ Pepsinogen $C^{*}$} & \multicolumn{2}{|c|}{ Ratio } \\
\hline & & $\overline{\bar{x}}$ & $\mathrm{SD}$ & $\overline{\mathbf{x}}$ & $\mathrm{SD}$ & $\overrightarrow{\mathrm{x}}$ & SD \\
\hline $\begin{array}{l}20-29 \\
30-39 \\
40-49 \\
50-59 \\
60-64\end{array}$ & $\begin{array}{r}60 \\
60 \\
53 \\
21 \\
6\end{array}$ & $\begin{array}{l}50 \\
61 \\
63 \\
73 \\
69\end{array}$ & $\begin{array}{l}20 \\
29 \\
27 \\
34 \\
37\end{array}$ & $\begin{array}{l}12 \\
15 \\
17 \\
19 \\
23\end{array}$ & $\begin{array}{r}7 \\
13 \\
11 \\
16 \\
6\end{array}$ & $\begin{array}{l}5.6 \\
5.1 \\
5.0 \\
5.2 \\
3.0\end{array}$ & $\begin{array}{l}4.1 \\
2.2 \\
3.1 \\
2.4 \\
1.4\end{array}$ \\
\hline
\end{tabular}

* significant ratio of within and between variances 


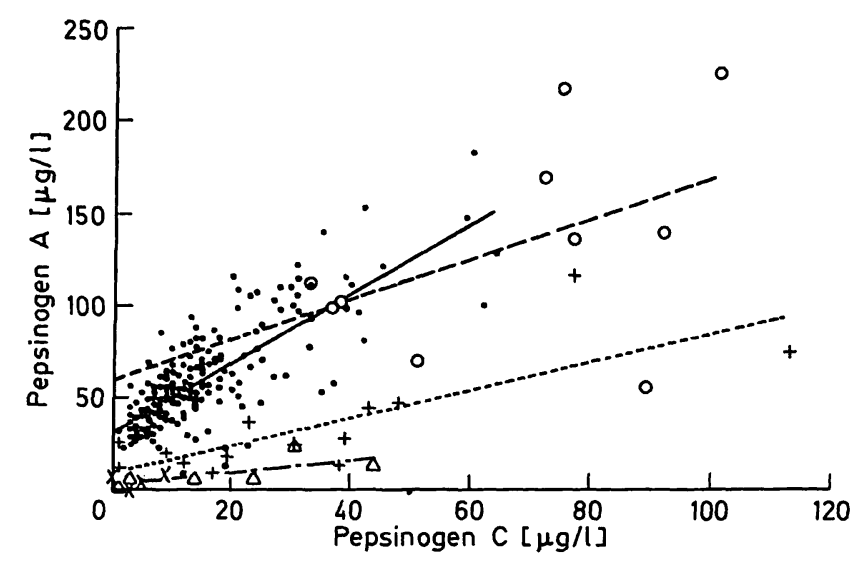

Fig. 5. Relationship between serum pepsinogen $A$ and serum pepsinogen $\mathrm{C}$ in blood donors and different groups of patients. Solid line: regression line $(r=0.779$; $y=1.88 x+30.87)$ in blood donors $(0)$. Dashed line: regression line $(r=0.473 ; y=1.09 x+60.23)$ in patients with duodenal ulcer $(0)$. Dotted line: regression line $(r=0.790 ; y=0.75 x+9.10)$ in patients having undergone partial gastrectomy $(+)$. Dotted-dashed line: regression line $(r=0.706 ; y=0.33 x+2.76)$ in patients with atrophic gastritis $(\triangle)$. Patients with total gastrectomy $(x)$.

\section{Discussion}

We describe the purification and radioimmunoassays of pepsinogens $A$ and $C$ and their serum concentration distribution in blood transfusion donors, in patients suffering from duodenal ulcer disease, in those having undergone partial or total gastrectomy, and in patients with achlorhydria.

With the purification of pepsinogens we followed partially the procedure described by Samloff (7). However for the separation of pepsinogen A from pepsinogen $C$ we used anion exchange chromatography on Mono $\mathrm{Q}^{\circledR}$ by FPLC ${ }^{\circledR}$. With a chloride gradient, pepsinogen $\mathrm{C}$ can be predicted to elute first from Mono $\mathrm{Q}^{\circledR}$, in agreement with the order of elution of pepsinogens from Mono $\mathrm{Q}^{{ }}$- and DEAE anion exchangers by a chloride gradient as described by other authors $(4,7,9)$. It has been shown in other studies $(7,10)$ that pepsinogen $A$ is immunologically distinct from pepsinogen $C$; since the first peak appeared to be immunologically distinct from the following 3 peaks of the elution profile, we assigned the first peak in figure 1 to pepsinogen $C$ and the others to pepsinogen $A$. The isozymogen profile of pepsinogen A from this study differs from that published before by Défize et al. (4), as these authors showed pepsinogen $A$ to have 4 isozymogens. The reason for this discrepancy is probably genetically determined. It is known that the isozymogen profile of pepsinogen $A$ is under genetic control (8), and the number of isozymogens of pepsinogen $A$ and their intensity varies individually.
From figure 1 it is evident that the ratio between proteolytic activity and absorbance is larger for the pepsinogen $C$ than for the pepsinogen A peaks. This finding has also been reported previously by Samloff (7).

In this study, the standards with the highest immunoreactivity were selected. For pepsinogen $C$ in blood donors we found a mean value comparable to that of the controls published by Samloff (7); however, for pepsinogen $\mathrm{A}$ in the blood transfusion donors we found a mean value which was twice the mean concentration reported by Samloff (7). In order to reach uniformity we corrected our standard with a factor of two.

Because of differences in assay characteristics and the studied populations, any comparison of our study with those of others has to be interpreted with great caution. Nevertheless it is possible to compare trends in different patient and control groups from this study with those reported in the literature.

Both pepsinogens showed a leptokurtic and positively skewed distribution of their serum concentrations. Square root transformation reduced both the leptokurtosis and skewness, and this finding is in agreement with other studies $(11,12)$. In nearly all publications relating to the serum level of pepsinogen $A$ in different age groups of control subjects, the same conclusion was reached as in this study, i. e. a gradual increase of pepsinogen $A$ with age, reaching a maximum at the sixth or seventh decade of life $(10,12-16)$. We also found an increase of serum pepsinogen $C$ in older healthy controls, as was also seen in other studies $(9$, 10).

The finding of a higher serum concentration of pepsinogen $\mathrm{A}$ in males than in females is in agreement with previous studies $(12-17,19)$. With respect to serum pepsinogen $\mathrm{C}$, the picture is more complicated; some authors described a significantly higher serum concentration in males than in females $(10,18)$, while, in agreement with our findings, a more recent study found no significant difference (9).

In this study, both serum pepsinogens $A$ and $C$ were increased in duodenal ulcer disease, as was previously reported for serum pepsinogen $\mathrm{A}(10,15,16,20,21)$ and serum pepsinogen $C(10,20)$. In contrast to other studies $(10,20)$, we observed a significant reduction of the pepsinogen $\mathrm{A}$ to pepsinogen $\mathrm{C}$ ratio in these patients. The reason for this discrepancy is not apparent, but may be related to the relatively small number of patients studied in the present report.

In patients having undergone partial gastrectomy we found a decrease of pepsinogen $\mathrm{A}$ in serum, while 
serum pepsinogen $\mathrm{C}$ showed an increase. This has also been reported by other authors $(3,15,22)$ for pepsinogen A, while Sipponen et al. (3) reported that serum pepsinogen $C$ increases in patients having undergone partial gastrectomy, as the atrophy of the mucosa aggravates.

Total gastrectomy caused a strong decrease in the serum concentrations of both pepsinogens, and their ratio as has been reported in other studies $(7,10)$.

Atrophic gastritis caused a decrease of serum pepsinogen $A$, while serum pepsinogen $C$ was as high as in blood donors. These results fit perfectly with those

\section{References}

1. Foltmann, B. (1981) Essays Biochem. 17, 52-84.

2. Samloff, I. M., Varis, K., Ihamaki, T., Siurala, M. \& Rotter, J. I. (1982) Gastroenterology 83, 204-209.

3. Sipponen, P., Samloff, I. M., Saukkonen, M. \& Varis, K. (1985) Gut 26, 1170-1182.

4. Défize, J., Pals, G., Pronk, J. C., Frants, R. R., Rimmelzwaan, C., Westerveld, B. D. \& Eriksson, A. W. (1985) Scand. J. Clin. Lab. Invest. 45, 649-655.

5. Hunter, W. M. \& Greenwood, F. C. (1962) Nature 194, $495-496$.

6. Scatchard, G. (1949) Ann. N. Y. Acad. Sci. 51, 660-672.

7. Samloff, I. M. (1982) Gastroenterology 82, 26-33.

8. Frants, R. R., Pronk, J. C., Pals, G., Défize, J., Westerveld, B. D., Meuwissen, S. G. M., Kreuning, J. \& Eriksson, A. W. (1984) Hum. Genet. 65, 385-390.

9. Matsusako, K., Itoh, M., Yokochi, K., Miyamoto, T., Joh, T., Takeuchi, T., Moriyama, A., Kato, T. \& Tanaka, R. (1987) Clin. Chim. Acta 169, 239-247.

10. Ichinose, M., Miki, K., Furihata, C., Kageyama, T., Hayashi, R., Niwa, H., Oka, H., Matsushima, T. \& Takahashi, K. (1982) Clin. Chim. Acta 126, 183-191.

11. Rotter, J. I., Wong, F. L., Samloff, I. M., Varis, K., Siurala, M., Ihamaki, T., Ellis, A. \& McConnell, R. B. (1982) Am. J. Hum. Genet. 34, 395-401. published in the literature for pepsinogen $\mathrm{A}(2,7,17)$ and pepsinogen $C(2,7)$.

In summary, we have developed radioimmunoassays for both pepsinogen $A$ and $C$ in human serum, and we have applied these assays to measurements in healthy blood donors, and in patients with duodenal ulcer, partial or total gastrectomy and atrophic gastritis.

\section{Acknowledgement}

The technical assistance of J.P. Giliams and the secretarial help of Lya Lieftink are gratefully acknowledged.

12. Pals, G., Westerveld, B. D., Défize, J., Pronk, J. C., Biemond, I., Meuwissen, S. G. M. \& Eriksson, A. W. (1985) Ann. Human Biol. 12, 403-411.

13. Axelsson, C. K., Szecsi, P. B. \& Damkjaer Nielsen, M. (1984) Scand. J. Gastroenterol. 19, 1114-1118.

14. Waldum, H. L., Straume, B. K., Burhol, P. G. \& Bredrup Dahl, L. (1980) Acta Paediatr. Scand. 69, 215-218.

15. Huang, S. C., Miki, K., Hirano, K., Hayashi, Y., Furihata, C., Shimizu, A., Ichinose, M., Oka, H., Matsushima, T. \& Takahashi, K. (1987) Clin. Chim. Acta 162, 85-96.

16. Samloff, I. M., Liebmann, W. M. \& Panitch, N. M. (1975) Gastroenterology 69, 83-90.

17. Tamm, A., Villako, K., Härkönen, M. \& Karonen, S.-L. (1984) Scand. J. Gastroenterol. 19, $1091-1094$.

18. Matzku, S., Zöller, M. \& Rapp, W. (1978) Digestion 18, $16-26$.

19. Pelissero, A., DiNapoli, A., Peyre, S. \& Sategna-Guidetti, C. (1986) J. Clin. Gastroenterol. 8, 499.

20. Samloff, I. M., Stemmerman, G. N., Heilbrun, L. K. \& Nomura, A. (1986) Gastroenterology 90, 570-576.

21. Nakanome, C., Akai, H. \& Goto, Y. (1983) Tohuku J. Exp. Med. 139, 151-158.

22. Stemmermann, G. N., Samloff, I. M., Nomura, A. \& Walsh, J. H. (1980) Dig. Dis. Sci. 25, 680-687.

Izak Biemond

Afdeling Maag-, Darm-, en Leverziekten

Gebouw 1, C4-P

Academisch Ziekenhuis

Postbus 9600

NL-2300 RC Leiden 
'

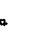

